\title{
PEMBUATAN BASIS DATA WARGA DAN PELATIHAN KETERAMPILAN SISTEM INFORMASI BAGI KADER POSYANDU DAN POSWINDU KELURAHAN KALIMULYA DEPOK
}

\author{
Defiana Arnaldy, Indri Neforawati, Yoyok Sabar Waluyo \\ Teknik Multimedia dan Jaringan Jurusan Teknik Informatika dan Komputer Politeknik Negeri Jakarta \\ defiana.arnaldy@tik.pnj.ac.id, indri.neforawati@tik.pnj.ac.id, yoyok.sw@tik.pnj.ac.id
}

\section{ABSTRAK}

Politeknik Negeri Jakarta sebagai lembaga pendidikan tinggi memiliki 3 (tiga) tugas besar, yaitu pendidikan, penelitian dan pengabdian masyarakat. Poin ketiga yakni pengabdian masyarakat merupakan bentuk kepedulian kalangan akademisi terhadap permasalahan yang terjadi di masyarakat. Kegiatan ini merupakan sarana untuk mengimplementasikan ilmu pengetahuan dan teknologi di lingkungan masyarakat. Politeknik Negeri Jakarta telah melakukan kerjasama dengan Pemerintahan Kota Depok dalam program Smart City yang menjadi program pemerintah Kota Depok. Kendala yang terjadi dalam mendukung program Smart City diantaranya adalah keterbatasan sumber daya khususnya kader posyandu dan poswindu. Selain itu masih konvensionalnya teknik pemasukan data-data warga dan sinkronisasi terhadap data di puskesmas. Pengabdian masyarakat yang dilaksanakan di Kelurahan Kalimulya Kecamatan Cilodong merupakan sebuah kegiatan yang menjadi sarana implementasi untuk peningkatan kemampuan keterampilan kader-kader posyandu dan poswindu dalam hal system informasi dan ketersediaan sebuah server basis data warga. Hasil yang diharapkan dalam kegiatan ini berupa meningkatnya keterampilan penggunaan komputer para kader dan tersedianya server basis data warga.

Kata kunci: basis data, depok, pengabdian, posyandu, smart city.

\section{PENDAHULUAN}

\subsection{Latar Belakang}

Kelurahan Kalimulya merupakan sebuah Kelurahan yang terletak pada Kecamatan Cilodong Kota Depok Provinsi Jawa Barat. Jumlah penduduk berdasarkan data di kelurahan tersebut berjumlah 18.567 jiwa diantaranya terdiri dari 1.973 remaja laki-laki dan 1.982 remaja perempuan. Jumlah penduduk tersebut tersebar menjadi 6 RW (Rukun Warga), dimana setiap RW memiliki dua buah Posyandu dan Poswindu. Kelurahan Kalimulya memiliki Posyandu dan Poswindu yang bergabung menjadi satu.

Kegiatan Posyandu dan Poswindu ini selain melakukan imunisasi untuk para bayi dan balita juga memberikan penyuluhan tentang kesehatan untuk para warganya. Kegiatan ini dilakukan sebagai usaha untuk meningkatkan kesehatan warga. Dalam pelaksanaannya setiap posyandu dan poswindu dilakukan oleh para kader-kader kesehatan yang terhubung dengan puskesmas.

Kendala yang utama terjadi adalah kurangnya keterampilan kader-kader posyandu dan poswindu dalam bidang sistem informasi khususnya penggunaan komputer. Selain itu juga proses yang dilakukan untuk sinkronisasi data warga dengan puskesmas dilakukan secara konvensional, sehingga untuk melakukan sinkronisasi data setiap kader perlu untuk pulang pergi ke puskesmas.
Kegiatan ini berencana untuk memberikan pelatihan kepada para kader untuk dapat menggunakan komputer sehingga proses sinkronisasi data warga dengan data puskesmas lebih efisien. Selain itu juga untuk mempermudah, proses pemasukan data-data dan penyimpannnya, dibuatkan sebuah server yang dapat menyimpan basis data warga disebuah komputer

\subsection{Tujuan}

Tujuan dari program ini adalah untuk memanfaatkan kader posyandu dan poswindu agar dapat mengoperasikan komputer untuk mengefisiensikan proses kerja di posyandu dan Poswindu. serta menyediakan server basis data warga sebagai sarana penyimpanan data warga di Posyandu dan Poswindu

\subsection{Deskripsi Program}

Program yang diusulkan untuk menyelesaikan permasalahan yang ada di Kelurahan binaan, terbagi menjadi dua bagian. Bagian pertama adalah membuat sebuah server basis data yang akan berisi data-data warga di Posyandu dan Poswindu. Bagian kedua yaitu mengadakan pelatihan kepada para kader-kader Posyandu dan Poswindu dalam menggunakan sistem informasi dalam hal ini dikhususkan penggunaan komputer.

Program ini dipilih sesuai dengan hasil survey yang telah dilaksanakan oleh tim sebelumnya, bahwa berdasarkan hasil wawancara secara langsung terhadap para kader posyandu dan poswindu. Hasil wawancara memberikan gambaran kurangnya keterampilan para 
kader dalam menggunakan media sistem informasi, sehingga sinkronisasi data menjadi tidak efisien.

Program ini dibutuhkan oleh masyarakat binaan khususnya para kader posyandu dan poswindu, dan secara umum oleh masyarakat. Dengan tersedianya sebuah server basis data di posyandu dan poswindu akan mempermudah dalam mengelola data warga, untuk melakukan sinkronisasi maupun keperluan lainnya yang berkaitan dengan kesehatan warga

\section{TINJAUAN PUSTAKA}

\subsection{Basis Data (Database)}

Basis Data adalah kumpulan informasi yang disimpan di dalam komputer secara sistematik sehingga dapat diperiksa menggunakan suatu program komputer untuk memperoleh informasi dari basis data tersebut. Perangkat lunak yang digunakan untuk mengelola dan memanggil kueri (query) basis data disebut sistem manajemen basis data (database management system, DBMS). Sistem basis data dipelajari dalam ilmu informasi.

Konsep dasar dari basis data adalah kumpulan dari catatan-catatan, atau potongan dari pengetahuan. Sebuah basis data memiliki penjelasan terstruktur dari jenis fakta yang tersimpan di dalamnya: penjelasan ini disebut skema. Skema menggambarkan objek yang diwakili suatu basis data, dan hubungan di antara objek tersebut. Ada banyak cara untuk mengorganisasi skema, atau memodelkan struktur basis data: ini dikenal sebagai model basis data atau model data. Model yang umum digunakan sekarang adalah model relasional, yang menurut istilah layman mewakili semua informasi dalam bentuk tabel-tabel yang saling berhubungan di mana setiap tabel terdiri dari baris dan kolom (definisi yang sebenarnya menggunakan terminologi matematika). Dalam model ini, hubungan antar tabel diwakili denga menggunakan nilai yang sama antar tabel. Model yang lain seperti model hierarkis dan model jaringan menggunakan cara yang lebih eksplisit untuk mewakili hubungan antar tabel. (Indrajani, 2014).

\subsection{Server}

Server merupakan sebuah sistem komputer yang menyediakan jenis layanan tertentu dalam sebuah jaringan komputer. Peladen didukung dengan prosesor yang bersifat scalable dan RAM yang besar, dan juga dilengkapi dengan sistem operasi khusus, yang disebut sebagai sistem operasi jaringan. Server juga menjalankan perangkat lunak administratif yang mengontrol akses terhadap jaringan dan sumber daya yang terdapat di dalamnya contoh sepertihalnya berkas atau pencetak, dan memberikan akses kepada stasiun kerja anggota jaringan.

Dilihat dari fungsinya, peladen bisa dikategorikan dalam beberapa jenis, seperti peladen aplikasi, peladen data maupun peladen proksi. Peladen aplikasi adalah peladen yang digunakan untuk menyimpan berbagai macam aplikasi yang dapat diakses oleh klien, peladen data sendiri digunakan untuk menyimpan data baik yang digunakan klien secara langsung maupun data yang diproses oleh peladen aplikasi. Peladen proksi berfungsi untuk mengatur lalu lintas di jaringan melalui pengaturan proksi. Orang awam lebih mengenal proxy server untuk mengkoneksikan komputer klien ke Internet. (Sutanta, 2007)

\subsection{Posyandu}

Posyandu adalah salah satu bentuk upaya kesehatan berbasis masyarakat yang sudah menjadi milik masyarakat serta menyatu dalam kehidupan dan budaya masyarakat. Meskipun dalam satu dasa warsa terakhir ini terjadi perubahan tatanan kepemerintahan di Indonesia, tetapi Posyandu masih tetap ada di tengah-tengah masyarakat.

Keberadaan Posyandu sangat diperlukan dalam mendekatkan upaya promotif dan preventif kepada masyarakat, utamanya terkait dengan upaya peningkatan status gizi masyarakat serta upaya kesehatan ibu dan anak. Peran dan dukungan Pemerintah kepada Posyandu melalui Puskesmas sangat penting untuk memfasilitasi pelaksanaan berbagai kegiatan kesehatan di Posyandu. (Kementerian Kesehatan, 2011).

\subsection{Kelurahan Kalimulya}

Kelurahan Kalimulya berdiri pada tanggal 14 Juni 1978 dulunya adalah salah satu hasil pemekaran dari Desa Kalibaru yang saat itu masuk wilayah Kecamatan Cibinong Kabupaten Bogor.

Adapun nama KALIMULYA terdiri dari dua suku kata KALI dan MULYA kata Kali/Sungai adalah Ciri Khas Batas Wilayah Kelurahan Kalimulya sebelah Timur Kali Kumpa dan sebelah Barat Kali Ciliwung. Sedangkan kata MULYA adalah Agung/Besar, karena salah satu tempat di pinggir Sungai Ciliwung terdapat mata air yang berbau busuk itu adalah salah satu Kebesaran Allah SWT. Maka di satukanlah dua suku kata tersebut menjadi nama KALIMULYA.

Kemudian dengan berdirinya Kota Administratif Depok pada Tanggal 18 Maret 1982, maka Kelurahan Kalimulya masuk Wilayah Kecamatan Sukmajaya Kotip Depok, pada tanggal 24 Maret 1994 perubahan Status Desa menjadi Kelurahan.

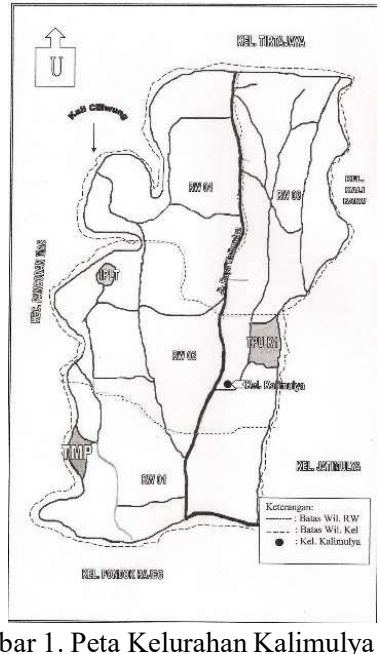

Gambar 1. Peta Kelurahan Kalimulya 


\section{HASIL DAN PEMBAHASAN}

Jenis kegiatan pengabdian kepada masyarakat berbasis Iptek bagi masyarakat (IbM) yang telah dilaksanakan berupa pembuatan basis data warga dan pelatihan keterampilan sistem informasi bagi kader posyandu dan poswindu kelurahan kalimulya. Kegiatan tersebut diselenggarakan sebagai bentuk partisipasi civitas akademika PNJ dalam pemberdayaan masyarakat, khususnya warga Kelurahan Kalimulya RW 01 .

\subsection{Pelaksanaan Kegiatan}

Kegiatan berupa pelatihan Penggunaan Microsoft Office (Word, Excel dan Power Point) serta Demo Penggunaan Server, dilakukan di Kelurahan Kalimulya Depok pada hari Sabtu, 29 September 2018 dari pukul 08.00 - 15.15 dan diikuti oleh kader posyandu dan poswindu Kelurahan Kalimulya Depok.

Pelatihan dibuka oleh Pak Suryadi, Lurah Kalimulya. Pelatihan ini dilakukan selama empat jam dan dilanjutkan dengan demo penggunaan server dan diskusi selama 2 jam diikuti oleh 27 Kader Posyandu dan Poswindu. Pemateri dalam pelatihan adalah sebagai berikut:

1. Mahasiswa dan Mahasiswi TMJ Semester 3 Pemberi materi pelatihan Microsoft Office (Word, Excel, dan Power Point)

2. Mahasiswa dan Mahasiswi TMJ Semester 5 Pemberi materi penggunaan server database.

Pelatihan yang diikuti oleh kader posyandu dan poswindu di Kelurahan Kalimulya diikuti secara lancar dan peserta menunjukkan antusiame yang tinggi. Mahasiswa dan Mahasiswi TMJ fokus untuk menuntun Ibu-Ibu Kader dalam menggunakan aplikasi. Para Kader menunjukkan ketertarikan yang besar dalam mengikuti pelatihan dan menerima demo yang diberikan dengan menggunakan Microsoft Word, Excel dan Power Point, meskipun beberapa mengalami kesulitan, namun para Mahasiswa dengan tenang membimbing Ibu-Ibu kader untuk mengikuti pelatihan dari awal hingga akhir

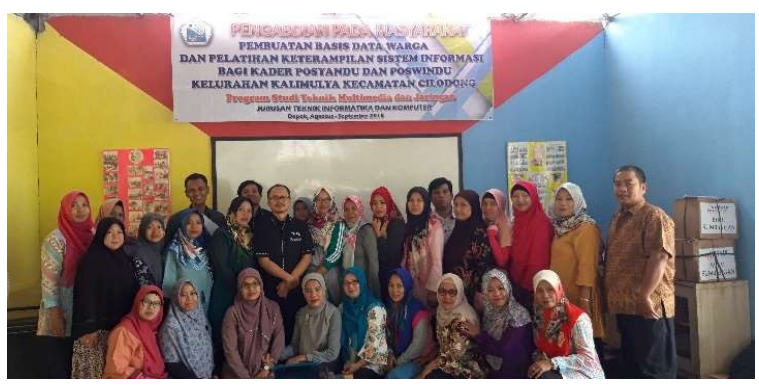

Gambar 2. Peserta Pelatihan Kader Posyandu

Para Kader juga antusias saat pemateri memberikan demo penggunaan server database, dan berharap pendataan mereka kemudian di kelurahan Kalimulya menjadi lebih lancar dan lebih tertata. Demi terealisasinya penggunaan database, perwakilan dari kelurahan juga berharap bahwa hal ini juga akan terintegrasi dengan data-data dari inter RW dan antar kelurahan lainnya.

\subsubsection{Cara kerja sistem}

Cara kerja server database adalah admin dari pihak kelurahan memasukan data warga setiap RT dan RW kedalam server database yang telah dibuat. Sebagai data awal dimasukan data warga RW 1 Kelurahan Kalimulya Kecamatan Cilodong Depok. Selanjutnya pemasukan data diserahkan kepada admin untuk memasukan data warga dari RW lainnya. Setelah datadata warga dimasukan dalam server database warga, selanjutnya apabila kader posyandu membutuhkan datadata warga tentang riwayat kesehatannya dapat dengan mudah mengakses server basisdata tersebut.

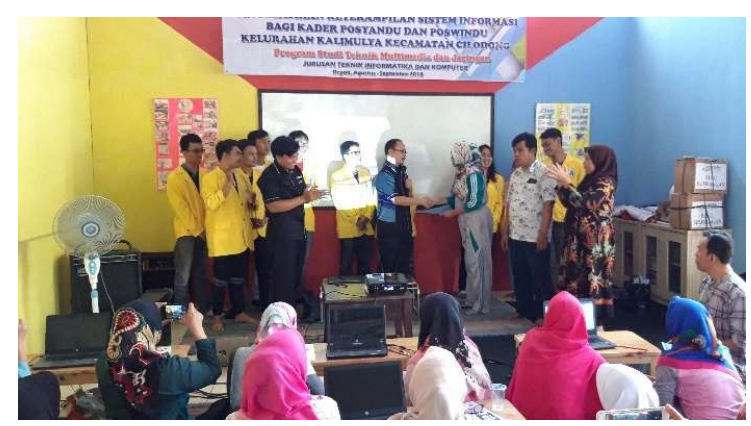

Gambar 3. Penyerahan server basis data

Server disimpan di kantor Kelurahan Kalimulya untuk mempermudah akses setiap warga. Rencana selanjutnya adalah menyimpan server-server kecil di setiap Posyandu dan Poswindu dan terintegrasi dengan server di Kantor Kelurahan. Dengan terintegrasinya setiap server, mempermudah para kader Posyandu dan Poswindu dalam melakukan pemeriksaan kesehatan warga Kalimulya yang tujuan utamanya adalah terintegrasi dengan data Puskesmas.

PNJ Berbagi Pengetahuan di Kelurahan Kalimulya, Depok IN SATEUT DEPOK, WILAYAH DEPOK

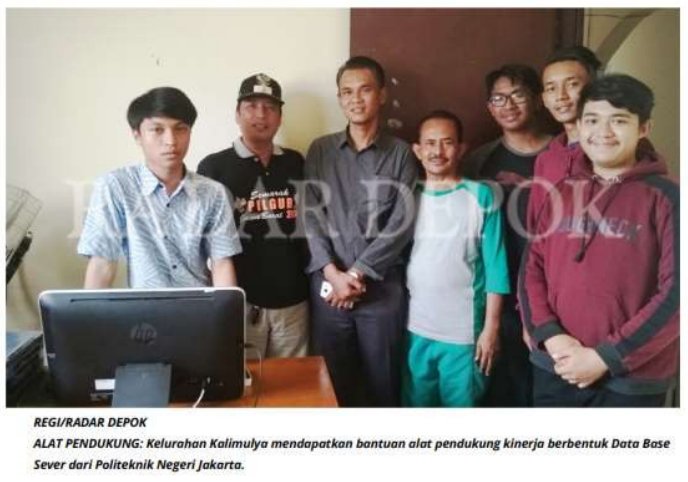

Gambar 4. Penempatan server basis data di kantor Kelurahan Kalimulya 


\section{PENUTUP}

\subsection{Kesimpulan}

IbM berbasis Prodi melalui Kegiatan pelatihan pembuatan server basis data warga dan pelatihan keterampilan sistem informasi bagi kader posyandu dan poswindu kelurahan kalimulya, antara lain:

a. Para kader Posyandu dan Poswindu dapat dengan mudah melakukan sinkronisasi data warga kalimulya RW 01

b. Para kader Posyandu dan Poswindu dapat memasukkan data-data warga kedalam sistem database dengan menggunakan aplikasi penunanjang lainnya seperti WORD, EXCEL, dan POWER POINT.

c. Meningkatkan keterampilan para kader Posyandu dan Poswindu dalam menggunakan komputer dan teknologi sistem informasi.

\subsection{Saran}

Menambahkan target monitoring untuk melakukan Saran untuk kelanjutan kegiatan adalah diperluasnya mitra kegiatan agar pelatihan dapat diberikan secara luas kepada seluruh kelurahan di Kota Depok. Selain itu kontribusi mitra baik dalam bentuk materi maupun fasilitas pelatihan sangat diharapkan untuk kelancaran kegiatan.

\section{DAFTAR PUSTAKA}

Indrajani. 2014. Pengantar Sistem Basis Data Case Study All in One. PT. Elex Media Komputindo. Jakarta.

Kementerian Kesehatan RI. 2011. Pedomana Umum Pengelolaan Posyandu. Kementerian Kesehatan RI bekerjasama dengan Kelompok Kerja Operasional (POKJANAL POSYANDU).

Sutanta, E. 2007. Komunikasi Data dan Jaringan Komputer. E-book. 